\title{
POTENSI PENGEMBANGAN STANDAR NASIONAL INDONESIA (SNI) PRODUK GARAM KONSUMSI BERYODIUM DALAM RANGKA MENINGKATKAN DAYA SAING
}

\section{POTENTIAL OF DEVELOPING INDONESIAN NATIONAL STANDARDS (SNI) FOR YODIUM SALT PRODUCTS TO INCREASE COMPETITIVENESS}

\author{
Ari Wibowo \\ Pusat Riset dan Pengembangan - Badan Standardisasi Nasional \\ Kompleks PUSPIPTEK Gedung 420, Kota Tangerang Selatan, Banten 15314 \\ E-mail: ari@bsn.go.id
}

\begin{abstract}
Abstrak
Berdasarkan Keputusan Presiden Nomor 69 tahun 1994 tentang pengadaan garam beryodium dan Keputusan Menteri Perindustrian No. 29/M/SK/2/1995 tentang Penggunaan tanda SNI secara wajib terhadap 10 macam produk industri, garam yang beredar di pasaran harus memenuhi SNI, artinya semua produk garam konsumsi yang beredar di Indonesia harus memenuhi persyaratan mutu SNI. Tahun 2020 kebutuhan garam diperkirakan sebanyak 4,2 juta ton sedangkan produksi garam nasional baru sebanyak 2,3 juta ton, disisi lain kualitas garam yang diproduksi petani umumnya rendah dan harus diolah kembali untuk dijadikan garam konsumsi maupun garam industri. Tujuan penelitian ini adalah untuk mengidentifikasi kebutuhan pengembangan SNI produk garam sehingga penerapan SNI untuk meningkatkan daya saing industri dapat terwujud. Data sekunder diperoleh melalui desk study, review Sistem Informasi SNI, sedangkan data primer diperoleh melalui diskusi, wawancara dengan produsen garam, praktisi di bidang Standardisasi. Hasil yang diperoleh seiring bertambah jumlah penduduk dan pertumbuhan industri, kebutuhan garam nasional selalu meningkat. Hingga Desember 2019 terdapat 39 SNI terkait dengan garam, SNI 3556:2016 menetapkan persyaratan kadar natrium klorida $(\mathrm{NaCl})$ minimal $94 \%$ dan kadar yodium sebagai $\mathrm{KIO}_{3}$ minimal $30 \mathrm{mg} / \mathrm{kg}$. Tinjauan Pemerintah terhadap industri pengolahan garam menyatakan kadar $\mathrm{NaCl}$ garam rakyat sebesar $81,1-86,91 \%$. Peran mengembangkan SNI terkait tata cara pemenuhan garam konsumsi, pemeliharaan tambak garam sangat bermanfaat yang dapat digunakan petani/UMKM sebagai acuan memproduksi garam.
\end{abstract}

Kata Kunci: Standar Nasional Indonesia, Garam, Konsumsi, Yodium

\begin{abstract}
Abstrak
Based on Presidential Decree No.69/1994 on iodized salt procurement and Decree Industry Minister No.29/M/SK/2/1995 concerning SNI marks for 10 kinds of products, salt must comply with SNI, meaning consumption salt products circulating in Indonesia must meet SNI quality requirements. In 2020, need for salt is estimated at 4.2 million tons, while national production is only 2.3 million tons, on other hand, salt quality produced by farmers is generally low and must be reprocessed into consumption or industrial salt. Research purpose is to identify SNI development need for salt products so that SNI application to improve industrial competitiveness can be realized. Secondary data were obtained through desk studies, SNI Information System, primary data were obtained through discussions, interviews, practitioners in Standardization field. Results obtained with increasing population and industrial growth, need for national salt always increases. Until December 2019 there are 39 SNIs related to salt, SNI 3556: 2016 stipulates requirements for $\mathrm{NaCl}$ at least 94\% and iodine levels as KIO3 minimal $30 \mathrm{mg} / \mathrm{kg}$. Government's review states that people's salt NaCl levels are 81.1-86.91\%. Role of developing SNI related to procedure for fulfilling consumption salt, maintaining salt ponds is very useful which can be used by farmers/MSMEs as reference for producing.
\end{abstract}

Keywords: Indonesian National Standard, Salt, Consumption, lodine

\section{PENDAHULUAN}

Garam merupakan salah satu kebutuhan pelengkap untuk pangan dan sumber elektrolit bagi tubuh manusia, garam adalah senyawa yang terbentuk dari reaksi asam dan basa, menurut Marihati dan Muryati (2008) garam di definisikan sebagai suatu kumpulan senyawa kimia yang bagian utamanya adalah $\mathrm{NaCl}$ dengan zat-zat pengotor terdiri dari CaSO4, MgSO4, MgCl2 dan lain-lain. Garam merupakan satu dari sembilan jenis bahan kebutuhan pokok masyarakat menurut keputusan Menteri Perindustrian dan Perdagangan No. 15/MPP/KEP/2/ 1998. Secara fisik, garam adalah benda padatan berwarna putih berbentuk kristal yang merupakan kumpulan senyawa dengan bagian terbesar $\mathrm{NaCl}(>80 \%)$ serta senyawa lainnya seperti magnesium klorida, magnesium sulfat, kalsium klorida, dan lain-lain. Garam diklasifikasikan sebagai garam konsumsi dan garam industri, hal ini didasarkan pada 
kandungan zat kimia yang terdapat dalam garam. Garam konsumsi memiliki $\mathrm{NaCl}$ minimal $94 \%$ dan harus memenuhi persyaratan kualitas garam konsumsi, Garam industri memiliki $\mathrm{NaCl}$ minimal $97 \%$. Khusus untuk industri pangan, kadar Ca dan Mg < 600 ppm (Purbani, 2000).

Berdasarkan Keputusan Presiden Republik Indonesia Nomor 69 tahun 1994 tentang pengadaan garam beryodium dan Keputusan Menteri Perindustrian No. 29/M/SK/2/1995 tentang pengesahan SNI dan Penggunaan tanda SNI secara wajib terhadap 10 macam produk industri, garam yang beredar di pasaran harus memenuhi SNI, ini artinya semua garam yang beredar di Indonesia harus mengandung yodium yaitu garam yang telah diperkaya dengan kalium iodat $\left(\mathrm{KIO}_{3}\right)$. Pada tahun 1995, Biro Pusat Statistik (BPS) dan UNICEF melakukan survei nasional tentang gangguan akibat kekurangan yodium (GAKY), data yang diperoleh menunjukkan bahwa semua propinsi di Indonesia kecuali Kalimantan Timur, rata rata penduduknya mengalami kekurangan yodium. Yodium merupakan mineral yang diperlukan oleh tubuh dalam jumlah yang relatif sangat kecil, tetapi mempunyai peranan yang sangat penting untuk pembentukan hormon tiroksin. Yodium selain dapat diperoleh dari garam beryodium, juga dapat diperoleh dari air minum, sayuran dan bahan makanan dari laut (Hena Sugiani dkk, 2015). Perlunya penambahan yodium ini (ditambahkan dalam bentuk $\mathrm{KIO}_{3}$ kalium iodat) dimaksudkan untuk mencukupi kebutuhan tubuh manusia akan zat yodium, gangguan akibat kekurangan yodium dapat mengakibatkan gondok, kretin, menurunnya kecerdasan dan untuk tingkat yang lebih berat dapat mengakibatkan gangguan otak dan pendengaran serta kematian bayi. Harga garam konsumsi beryodium yang relatif murah dan terjangkau oleh semua lapisan masyarakat membuat pemerintah memilih garam dapur menjadi media penyampaian yodium ke dalam tubuh (Hena Sugiani dkk, 2015). Usaha produksi garam rakyat merupakan salah satu roda penggerak perekonomian karena menyediakan lapangan kerja terutama bagi masyarakat di kawasan pesisir Indonesia dan menjadi sarana untuk mengentaskan kemiskinan.

Standardisasi merupakan salah satu alat (tools) kebijakan pemerintah dalam menata struktur ekonomi secara lebih baik dan memberikan perlindungan kepada masyarakat, SNI membantu masyarakat memilih produk yang berkualitas dan membantu konsumen terbebas dari produk yang berbahaya bagi keselamatan hidup, kesehatan, ataupun lingkungan. SNI mendorong terciptanya suatu produk dengan standar tertentu yang hanya bisa dihasilkan jika proses produksinya memenuhi kriteria tertentu. Berdasarkan UU SPK No.20 Tahun 2014, penilaian kesesuaian bertujuan a. Meningkatkan jaminan mutu, efisiensi produksi, daya saing nasional, persaingan usaha yang sehat dan transparan dalam perdagangan, kepastian usaha, dan kemampuan Pelaku Usaha, serta kemampuan, inovasi teknologi; b. Meningkatkan perlindungan kepada konsumen, Pelaku Usaha, tenaga kerja, dan masyarakat lainnya, serta negara, baik dari aspek keselamatan, keamanan, kesehatan, maupun pelestarian fungsi lingkungan hidup; dan c. Meningkatkan kepastian, kelancaran, dan efisiensi transaksi perdagangan Barang dan/atau Jasa di dalam negeri dan luar negeri.

Dalam pengambilan keputusan untuk membeli suatu barang atau produk, masyarakat memiliki suatu pertimbangan tertentu sesuai dengan motivasi dan kebutuhan masing-masing (DiClemente \& Hantula, 2003). SNI garam mendorong terciptanya suatu produk dengan standar tertentu yang hanya bisa dihasilkan jika proses produksinya memenuhi kriteria tertentu, SNI dapat digunakan untuk menilai dan menguji suatu produk yang dimiliki oleh pelaku usaha atau produsen. Kesesuaian terhadap persyaratan SNI dilakukan melalui mekanisme Sertifikasi Produk Penggunaan Tanda SNI (SPPT SNI), sertifikat dikeluarkan oleh Lembaga Sertifikasi Produk (LSPro) yang telah diakreditasi oleh Komite Akreditasi Nasional. Hingga tahun 2020 BSN telah menetapkan SNI sebanyak 11.000 standar mencakup standar Barang, Jasa, Sistem, Proses, atau Personal. Penerapan SNI produk dibuktikan melalui pemilikan sertifikat dan/atau pembubuhan Tanda SNI dan/atau Tanda Kesesuaian. Sebagai tanda jaminan bahwa produk tersebut telah memenuhi persyaratan dalam SNI adalah produsen berhak mencantumkan tanda SNI sesuai dengan ketentuan yang berlaku (Badan Standardisasi, 2011). Oleh karena itu, produk yang bertanda SNI telah dijamin memberikan kenyamanan, keamanan, dan keselamatan bagi masyarakat sebagai konsumen.

Penelitian ini bertujuan untuk untuk mengidentifikasi kebutuhan pengembangan SNI produk garam sehingga tujuan penerapan SNI yang salah satunya merupakan kebijakan dan strategi penting Pemerintah untuk meningkatkan daya saing industri dapat terwujud.

\section{TINJAUAN PUSTAKA}

\subsection{Sumber Garam}

Indonesia merupakan negara kepulauan dengan panjang pesisir pantainya yang mencapai 81.000 
km, ditambah Indonesia memiliki 30 sentra produksi garam yang tersebar di tujuh provinsi, yaitu Jawa Barat, Jawa Tengah, Jawa Timur, Nusa Tenggara Barat, Nusa Tenggara Timur, Sulawesi Tengah, Sulawesi Selatan. Luas Iahan mencapai 19.600 hektar (ha). Menurut Burhanuddin (2001), secara umum, terdapat tiga sumber utama garam, antara lain:

a. Air Laut dan Air Danau Asin Sebesar 40\% produksi garam dunia berasal dari air laut. Beberapa negara produsen garam yang berasal dari air laut antara lain Australia, Brazil, RRT India, Kanada dan Indonesia. Sementara itu, produksi garam dunia yang berasal dari air danau asin menyumbangsebesar $20 \%$ dari total produksi dunia. Negara produsen garam yang berasal dari air danau asin antara lain: Yordania (Laut Mati), Amerika Serikat (Great Salt Lake), RRT dan terdapat beberapa daerah di Australia.

b. Tambang Garam Produksi garam dunia yang berasal dari dalam tanah (tambang garam) memiliki pangsa sebesar kurang lebih $40 \%$ dari total produksi garam dunia. Tambangtambang garam terutama berada di Negara Amerika Serikat, Belanda, RRT dan Thailand.

c. Air Dalam Tanah Garam yang berasal dari air dalam tanah memiliki pangsa yang amat kecil dari total produksi garam dunia. Kecilnya produksi garam yang berasal dari air tanah disebabkan biaya yang harus dikeluarkan untuk memproduksi garam tersebut dinilai tidak efisien (tidak ekonomis).

Hampir keseluruhan garam Indonesia diproduksi dengan menggunakan teknologi penguapan air laut dengan tenaga sinar matahari (solar evaporation). Secara umum, pembuatan garam air laut dengan metode tersebut dilakukan melalui proses pemekatan dan proses pemisahan garam (kristalisasi) (Assadad dan Utomo, 2011). Proses pemekatan dilakukan dengan menguapkan airnya dengan panas matahari. Setelah garam melalui proses kristalisasi maka garam akan mengandung berbagai macam unsur mineral lainnya yang disebut dengan impurities yaitu sulfat, magnesium dan kalsium

\subsection{Pengertian Garam Beryodium}

Garam beryodium adalah garam konsumsi yang mengandung komponen-komponen utama $\mathrm{NaCl}$ minimal $94,7 \%$, air laut maksimal $5 \%$ dan $\mathrm{K}_{3} \mathrm{O}_{3}$ sebanyak $30-80$ ppm $(\mathrm{mg} / \mathrm{kg})$ serta senyawa-senyawa lainnya. Berdasarkan SNI 3556:2016, garam konsumsi beryodium adalah produk bahan makanan yang berbentuk padat dengan komponen utamanya $\mathrm{NaCl}$ dengan penambahan / fortifikasi $\mathrm{KIO}_{3}$. Klasifikasi garam nasional dikelompokkan menjadi dua jenis garam yaitu garam konsumsi dan garam industri berdasarka Peraturan Menteri Perindustrian No. 88/M-IND/PER/10/2014 tentang perubahan atas Peraturan Menteri Perindustrian No. 134/MIND/PER/10/2009 tentang peta panduan (roadmap) pengembangan klaster industri garam. Garam konsumsi adalah garam yang digunakan untuk konsumsi atau dapat diolah menjadi garam rumah tangga dan garam diet untuk konsumsi masyarakat. Garam konsumsi terbagi menjadi 2 (dua) yaitu:

- Garam rumah tangga, adalah garam konsumsi beryodium dengan kandungan $\mathrm{NaCl}$ minimal 94\% atas dasar basis kering (adbk) air maksimal 7\%, bagian yang tidak larut dalam air maksimal 0,5 mg/kg (adbk), Kadmium (Cd) maksimal 0,5 mg/kg, Timbal (Pb) maksimal 10,0 mg/kg, Raksa (Hg) maksimal 0,1 mg/kg dan cemaran Arsen (As) maksimal $0,1 \mathrm{mg} / \mathrm{kg}$ serta Kalium lodate (KIO3) minimal $30 \mathrm{mg} / \mathrm{kg}$ yang berbentuk padat dan dapat dikonsumsi langsung oleh masyarakat.

- Garam diet, adalah garam konsumsi beryodium berbentuk cairan/padat dengan kadar $\mathrm{NaCl}$ maksimal $60 \%$ (adbk) serta $\mathrm{KIO}_{3}$ minimal $30 \mathrm{mg} / \mathrm{kg}$ yang dapat di konsumsi langsung oleh masyarakat.

Garam industri adalah garam yang digunakan sebagai bahan baku/penolong pada proses produksi, garam industri digunakan untuk: industri kimia, industri aneka pangan, industri pharmasi, industri perminyakan, industri penyamakan kulit, water treatment.

\subsection{Teknologi Pembuatan Garam di Indonesia}

Tercapainya swasembada garam nasional secara berkelanjutan merupakan kondisi ideal bagi Indonesia yang memiliki potensi alamiah sebagai produsen garam (Dharmayanti, S. dkk, 2013). Pembuatan garam di Indonesia umumnya diproduksi dengan menggunakan teknologi penguapan air laut dengan tenaga sinar matahari (solar evaporation). yaitu penguapan dengan tenaga sinar matahari di ladang pembuatan garam, penguapan dengan tenaga panas bahan bakar dalam suatu evaporator dan kristalisasi garamnya dalam suatu crystallizer, pemisahan elektrokimia larutan garam dengan proses elektrolisa kemudian kristalisasi dengan crystallizer (Agustina dll, 2013). Metode yang umum dilakukan di negara tropis, termasuk Indonesia, yaitu sistem kristalisasi total air laut. Prinsip utama metode ini adalah kristalisasi garam dari air laut dengan menggunakan sinar matahari untuk menguapkan air laut (L. Assadad 
dan B. S. B. Utomo, 2011). Proses solar evaporation secara lebih detail dilakukan melalui tahapan-tahapan berikut (Puska PDN, 2011):

1. Air laut dimasukkan ke dalam waduk penampungan pada saat pasang melalui saluran induk;

2. Dari waduk penampungan garam dipompa ke areal penguapan pada level yang tertinggi;

3. Dari areal penguapan yang mempunyai level paling tinggi air dialirkan secara gravitasi ke petak penguapan lainnya. Dalam perjalanannya air laut dipetak penguapan ini mendapatkan pemanasan sinar matahari dan hembusan angin sehingga terjadilah penguapan, hingga air laut menjadi jenuh (konsentrasi air garam tinggi atau pekat);

4. Air laut yang jenuh dialirkan ke petak kristalisasi untuk mengkristalkan garam;

5. Di petak kristalisasi ini, garam dibiarkan mengendap dengan jangka waktu:

- Pegaraman Rakyat tiap umur garam 4-6 hari lalu dipanen

- Pegaraman PT. Garam tiap umur +/- 10 hari lalu dipanen

6. Garam yang sudah dipungut lalu diangkut ke gudang untuk diproses lebih lanjut. Langsung dikarungi dan dijual sebagai garam bahan baku Dicuci (washing), dikeringkan (drying) dan digiling (crushing) menjadi garam meja (halus).

Walaupun reaksi asam dengan basa disebut reaksi penetralan, tetapi hasil reaksi (garam) tidak selalu bersifat netral. Sifat asam basa dari larutan garam bergantung pada kekuatan asam dan basa penyusunnya. Garam yang berasal dari asam kuat dan basa kuat bersifat netral, disebut garam normal, contohnya $\mathrm{NaCl}$ dan $\mathrm{KNO}_{3}$. Garam yang berasal dari asam kuat dan basa lemah bersifat asam dan disebut garam asam, contohnya adalah $\mathrm{NH}_{4} \mathrm{Cl}$. Garam yang berasal dari asam lemah dan basa kuat bersifat basa dan disebut garam basa, contohnya adalah $\mathrm{CH}_{3} \mathrm{COONa}$. Contoh asam kuat adalah $\mathrm{HCl}, \mathrm{HNO}_{3}, \mathrm{H}_{2} \mathrm{SO}_{4}$. Adapun $\mathrm{KOH}$, $\mathrm{NaOH}, \mathrm{Ca}(\mathrm{OH})_{2}$ termasuk basa kuat. Umumnya zat-zat dengan sifat yang berlawanan, seperti asam dan basa cenderung bereaksi satu sama lain. Reaksi asam dan basa merupakan pusat kimiawi sistem kehidupan, lingkungan, dan proses-proses industri yang penting. Reaksi antara asam dan basa akan menghasilkan garam dan air.

\subsection{Produk SNI Wajib}

Pengertian standar adalah dokumen tertulis yang berisi aturan, pedoman, atau karakteristik suatu barang dan/jasa atau proses dan metode yang berlaku umum dan digunakan secara berulang. Penyusunan standar pada prinsipnya didasarkan atas kebutuhan dan hasil konsensus para pemangku kepentingan untuk mencapai keteraturan dalam berbagai aspek ekonomi, sosial, lingkungan guna menunjang pembangunan berkelanjutan. SNI adalah standar yang ditetapkan oleh BSN dan berlaku secara nasional (PP 102, 2000). Standardisasi secara umum merupakan rangkaian proses mulai dari pengembangan standar (pemrograman, perumusan, penetapan dan pemeliharaan standar) dan penerapan standar yang dilaksanakan secara tertib dan bekerja sama dengan para pemangku kepentingan (UU SPK No.20 Tahun 2014). SNI pada dasarnya adalah bersifat voluntary (sukarela), namun apabila standar tersebut menyangkut kepentingan keselamatan, keamanan, kesehatan dan kelestarian fungsi lingkungan hidup, maka penerapannya diberlakukan secara wajib oleh instansi teknis (PP 102 Tahun 2000).

Produk garam konsumsi beryodium berdasarkan kepada Keputusan Presiden Republik Indonesia Nomor 69 tahun 1994 tentang pengadaan garam beryodium dan Keputusan Menteri Perindustrian No. 29/M/SK/2/1995 tentang pengesahan SNI dan Penggunaan tanda SNI secara wajib terhadap 10 macam produk industry, garam yang beredar di pasaran harus memenuhi SNI, ini artinya semua garam yang beredar di Indonesia harus mengandung yodium yaitu garam yang telah diperkaya dengan $\mathrm{KIO}_{3}$. Penerapan produk bertanda SNI dibuktikan melalui pemilikan sertifikat dan/atau pembubuhan Tanda SNI dan/atau Tanda Kesesuaian (Isharyadi, 2015). Sebagai tanda jaminan bahwa produk tersebut telah memenuhi persyaratan dalam SNI adalah produsen berhak mencantumkan tanda SNI sesuai dengan ketentuan yang berlaku (Komite Akreditasi Nasional, 2016). Logo produk bertanda SNI diperlihatkan pada Gambar 1.

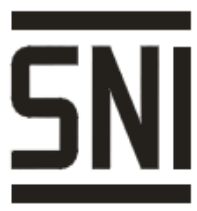

\section{No. SNI \\ Kode lembaga sertifikasi produk}

Gambar 1. Tanda SNI pada produk

Tanda SNI pada produk yang belum wajib SNI berfungsi sebagai tanda bahwa produk tersebut memiliki keunggulan (value added) karena telah disertifikasi. Setidaknya ada tiga pihak yang memperoleh manfaat langsung atas penerapan SNI suatu produk. Pihak yang 
pertama adalah produsen. SNI mendorong terciptanya suatu produk dengan standar tertentu, yang hanya bisa dihasilkan jika proses produksinya memenuhi kriteria tertentu. Untuk mencapai itu, produsen akan berusaha untuk mencari proses yang efisien dan efektif, mulai dari pemilihan bahan baku, proses produksi, sampai dengan pengemasan dan distribusi. Dengan kata lain, produsen akan terus melakukan inovasi sehingga produk yang dihasilkannya memiliki daya saing di pasar. Pihak berikutnya tentu saja adalah konsumen. Adanya SNI akan membantu konsumen untuk memilih produk yang berkualitas. Adanya SNI akan membantu konsumen terbebas dari produk yang berbahaya bagi keselamatan hidup, kesehatan, ataupun lingkungan. SNI juga membuat konsumen dapat menikmati barang yang sesuai antara harga dan kualitasnya. Kemudahan menentukan pilihan produk yang baik dan tidak dapat dilakukan salah satunya dengan memeriksa, apakah produk-produk tersebut memiliki SNI atau tidak. Terutama untuk produk-produk yang SNI-nya masih bersifat sukarela. Pihak terakhir yang mendapatkan manfaat langsung adalah pemerintah sendiri. Adanya SNI membuat pasar di dalam negeri memiliki mekanisme perlindungan dari serbuan barang-barang asing yang tidak diketahui kualitasnya. Manfaat yang lain,dengan penerapan SNI yang lebih luas, maka akan tumbuh dinamika ekonomi baru, di mana para produsen akan berusaha untuk mendapatkan SNI atas produk mereka, sedangkan di masyarakat akan tumbuh lebih banyak lembaga sertifikasi produk yang juga kredibel untuk menilai dan menguji suatu produk.

\section{METODE PENELITIAN}

Penelitian ini mengolah data primer dan data sekunder dengan metode kualitatif deskriptif. Data sekunder diperoleh dari studi literatur, identifikasi SNI, dan Regulasi yang terkait dengan industri garam konsumsi beryodium, sedangkan data primer diperoleh melalui wawancara dengan pelaku usaha (produsen) garam, diskusi dengan praktisi di bidang standardiasi. Menurut Hardiansyah, Haris. 2012, teknik analisis kualitatif yang digunakan dalam penelitian ini menggunakan langkah-langkah analisis sebagai berikut :

a. Pengumpulan data

b. Reduksi data

Reduksi data dilakukan melalui proses pemilihan data dan dilakukan secara terus menerus. Pemusatan perhatian pada penyederhanaan, pengabstraksian, dan transformasi data kasar yang muncul di lapangan.

c. Penyajian data

Data yang telah direduksi disajikan dalam bentuk teks naratif guna mempermudah pemahaman, penafsiran data dan penarikan kesimpulan. Penarikan kesimpulan atau verifikasi merupakan langkah terakhir dari analisis.

\section{HASIL DAN PEMBAHASAN}

\subsection{Data Produksi dan Impor Produk Garam} Kebutuhan garam setiap tahun selalu meningkat seiring dengan bertambahnya jumlah penduduk dan pertumbuhan industri. Pada 2019 kebutuhan garam nasional diperkirakan naik $5,98 \%$ menjadi 4,2 juta ton. Oleh karena itu, pemerintah mengalokasikan impor garam pada 2019 naik 0,2\% menjadi 2,72 juta ton dibandingkan 2018 yang sebesar 2,71 juta ton. Kenaikan tertinggi impor garam terjadi pada 2017, yaitu sebesar $19, \%$ dari 2,1 juta ton menjadi 2,6 juta ton. Total produksi garam nasional pada 2019 diperkirakan menurun 14,4\% menjadi 2,3 juta ton. Padahal, produksi garam pada 2017-2018 meningkat masing-masing sebesar $561,3 \%$ dan $144,7 \%$ menjadi 1,1 juta dan 2,7 juta ton. Penurunan terbesar produksi garam nasional terjadi pada 2016, yaitu mencapai 93,23\% dari 2,5 juta ton menjadi 168 ribu ton (Kementerian Koordinator Bidang Perekonomian, 2019).

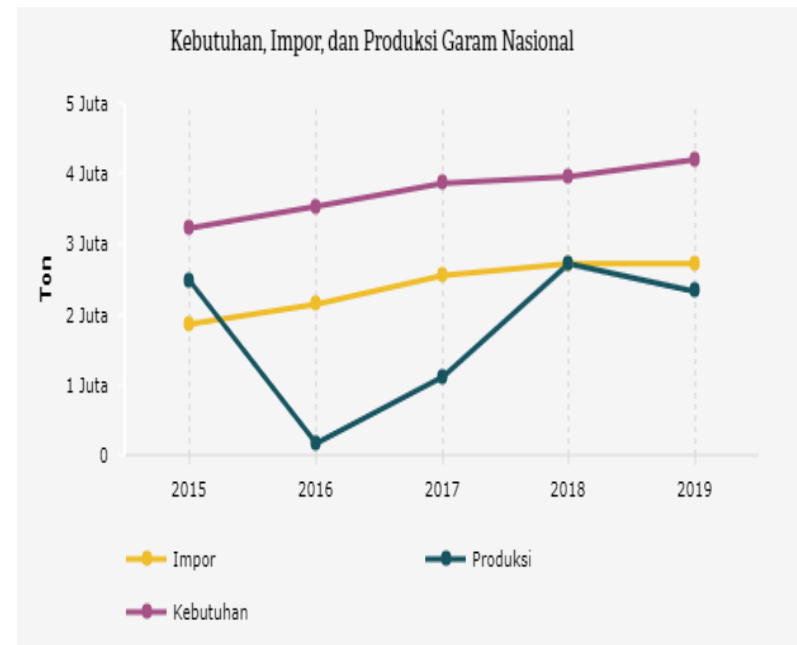

Gambar 2 Kebutuhan Impor dan Produksi Garam nasional

\subsection{Standar Nasional Indonesia terkait Garam}

Hingga Desember 2019 BSN telah menetapkan sebanyak 39 SNI terkait dengan garam yang ditetapkan dari tahun 1987 s.d 2019, 
dari $39 \mathrm{SNI}$ tersebut terdapat $29 \mathrm{SNI}$ yang masih berlaku dan $10 \mathrm{SNI}$ yang statusnya sudah tidak berlaku (Tabel 2).

Tabel 1 SNI Terkait Garam Penetapan Tahun 1987 s.d 2019

\begin{tabular}{|c|c|c|c|}
\hline No & No SNI & Judul & Status \\
\hline 1 & $\begin{array}{l}\text { SNI } \\
8446: 2017\end{array}$ & $\begin{array}{l}\text { Ketentuan gudang } \\
\text { komoditas garam }\end{array}$ & Berlaku \\
\hline 2 & $\begin{array}{l}\text { SNI } \\
3556: 2016\end{array}$ & $\begin{array}{l}\text { Garam konsumsi } \\
\text { beryodium }\end{array}$ & Berlaku \\
\hline 3 & $\begin{array}{l}\text { SNI } \\
8207: 2016\end{array}$ & $\begin{array}{l}\text { Garam industri } \\
\text { aneka pangan }\end{array}$ & Berlaku \\
\hline 4 & $\begin{array}{l}\text { SNI } \\
8209: 2016\end{array}$ & $\begin{array}{l}\text { Garam konsumsi } \\
\text { cair beryodium }\end{array}$ & Berlaku \\
\hline 5 & $\begin{array}{l}\text { SNI } \\
8208: 2016\end{array}$ & Garam diet & Berlaku \\
\hline 6 & $\begin{array}{l}\text { SNI } \\
4435: 2017\end{array}$ & $\begin{array}{l}\text { Garam bahan baku } \\
\text { untuk garam } \\
\text { konsumsi } \\
\text { beryodium }\end{array}$ & Berlaku \\
\hline 7 & $\begin{array}{l}\text { SNI } \\
8041: 2015\end{array}$ & $\begin{array}{l}\text { Metode uji standar } \\
\text { untuk menentukan } \\
\text { ketahanan ritsleting } \\
\text { terhadap } \\
\text { semprotan garam } \\
\text { (Kabut) (ASTM } \\
\text { D2059/D2059M-03 } \\
\text { (Reapproved 2009), } \\
\text { IDT) }\end{array}$ & Berlaku \\
\hline 8 & $\begin{array}{l}\text { SNI } \\
\text { 0303:2012 }\end{array}$ & $\begin{array}{l}\text { Garam untuk } \\
\text { industri soda } \\
\text { kaustik }\end{array}$ & Berlaku \\
\hline 9 & $\begin{array}{l}\text { SNI } \\
3556: 2010\end{array}$ & $\begin{array}{l}\text { Garam konsumsi } \\
\text { beryodium }\end{array}$ & $\begin{array}{c}\text { tidak } \\
\text { berlaku }\end{array}$ \\
\hline 10 & $\begin{array}{l}\text { SNI 05- } \\
\text { 6042-1999 }\end{array}$ & $\begin{array}{l}\text { Cara uji unjuk kerja } \\
\text { mesin iodisasi } \\
\text { garam tipe bintang } \\
\text { (star feeder) }\end{array}$ & Berlaku \\
\hline 14 & $\begin{array}{l}\text { SNI 04- } \\
6298-2000\end{array}$ & $\begin{array}{l}\text { Pengujian korosi } \\
\text { akibat kabut garam } \\
\text { air laut pada modul } \\
\text { fotovoltaik }\end{array}$ & Berlaku \\
\hline 15 & $\begin{array}{l}\text { SNI 02- } \\
4875-1998\end{array}$ & $\begin{array}{l}\text { Cara uji unjuk kerja } \\
\text { mesin iodisasi } \\
\text { garam tipe sabuk } \\
\text { dan ulir }\end{array}$ & $\begin{array}{c}\text { Masih } \\
\text { Berlaku }\end{array}$ \\
\hline 16 & $\begin{array}{l}\text { SNI 06- } \\
4577-1998\end{array}$ & $\begin{array}{l}\text { Kulit buaya mentah } \\
\text { awetan garam } \\
\text { basah }\end{array}$ & Berlaku \\
\hline 17 & $\begin{array}{l}\text { SNI 04- } \\
4519.2-1998\end{array}$ & $\begin{array}{l}\text { Pengujian } \\
\text { lingkungan - Bagian } \\
2 \text { : Pengujian - Uji } \\
\text { kabut : Kabut } \\
\text { garam }\end{array}$ & Berlaku \\
\hline 18 & $\begin{array}{l}\text { SNI 02- } \\
4506-1998\end{array}$ & $\begin{array}{l}\text { Cara uji untuk kerja } \\
\text { mesin iodisasi } \\
\text { garam tipe sabuk } \\
\text { (belt conveyor) }\end{array}$ & Berlaku \\
\hline
\end{tabular}

\begin{tabular}{cccc} 
No & No SNI & \multicolumn{1}{c}{ Judul } & Status \\
\hline 19 & $\begin{array}{l}\text { SNI 02- } \\
\text { 4505-1998 }\end{array}$ & $\begin{array}{l}\text { Cara uji kerja mesin } \\
\text { iodisasi garam tipe } \\
\text { piring putar }\end{array}$ & Berlaku \\
& &
\end{tabular}

20 SNI 014435-1998

Garam bahan baku

tidak untuk garam berlaku konsumsi

21 SNI 01$4435-2000$

Garam bahan baku untuk industri garam beryodium

22 SNI 013556.2-1999

23 SNI 013556.1-1999

24 SNI 01$3556-2000$

Garam meja

berlaku

berlaku

tidak

berlaku

Garam gurih

tidak

berlaku

Garam konsumsi

beryodium

25 SNI 013556-1999

26 SNI 01. 3556-1994

Garam dapur

Garam konsums

tidak berlaku

tidak

berlaku

tidak

berlaku

27 SNI 012899-1992

Garam meja dan konsumsi, Cara uji

tidak berlaku

28 SNI 012899.1-2000

Cara uji anti kempal dalam garam meja

29 SNI 012899-2000

Cara uji garam meja dan garam konsumsi

30 SNI 092663-1992

Cara uji ketahanan terhadap air, larutan garam, minyak pelumas dan cairan rem untuk kampas rem kendaraan bermotor

31 SNI 062561-1992

Garam dalapon teknis, Mutu dan cara uji

32 SNI 012359-1991

33 SNI 070479-1989

Produk perikanan, Penentuan kadar garam

Ketahanan korosi dipercepat dengan semprot kabut garam asam asetat - garam tembaga, Cara uji

34 SNI 070478-1989

Tahan korosi dipercepat dengan semprot kabut garam asam asetat, Cara uji

35 SNI 070413-1989

Cara uji ketahanan

Berlaku

Berlaku

Berlaku Berlaku 


\begin{tabular}{cccc}
\hline \hline No & No SNI & \multicolumn{1}{c}{ Judul } & Status \\
\hline 37 & SNI 07- & $\begin{array}{l}\text { Alat uji korosi } \\
\text { dengan semprot } \\
\text { kabut garam }\end{array}$ & Berlaku \\
& $0414-1989$ & $\begin{array}{l}\text { Garam beryodium } \\
38\end{array}$ & BNI 01- \\
& $\begin{array}{l}\text { S223-1987 } \\
\text { 39 }\end{array}$ & SNI 01- & lodisasi garam \\
& $0221-1987$ & konsumsi & Berlaku \\
\hline
\end{tabular}

\begin{tabular}{llll}
\hline No & \multicolumn{1}{c}{ Jenis uji } & Satuan & Persyaratan \\
\hline 4 & $\begin{array}{l}\text { Yodium dihitung } \\
\text { sebagai kalium iodat } \\
\text { (KIO3) adbk }\end{array}$ & $\mathrm{mg} / \mathrm{kg}$ & min. 30 \\
5 & Cemaran logam : & $\mathrm{mg} / \mathrm{kg}$ & maks. 0,5 \\
5.1 & Kadmium $(\mathrm{Cd})$ & $\mathrm{mg} / \mathrm{kg}$ & maks. 10,0 \\
5.2 & Timbal $(\mathrm{Pb})$ & $\mathrm{mg} / \mathrm{kg}$ & maks. 0,1 \\
5.3 & Raksa $(\mathrm{Hg})$ & $\mathrm{mg} / \mathrm{kg}$ & maks. 0,1 \\
6 & Cemaran Arsen (As) & \\
CATATAN 1 b/b adalah bobot/bobot & \\
\multicolumn{4}{l}{ CATATAN 2 adbk adalah atas dasar bahan kering } \\
\hline
\end{tabular}

konsumsi beryodium didapat bahwa penetapan SNI garam konsumsi beryodium pertama kali ditetapkan SNI 01-3556-2000 Garam konsumsi beryodium, selanjutnya kemudian di revisi menjadi SNI 3556:2010 Garam konsumsi beryodium dan terakhir direvisi menjadi SNI 3556:2016 Garam konsumsi beryodium. Adapun perbedaan antara SNI Garam konsumsi beryodium terletak pada persyaratan mutu seperti yang disajikan di Tabel 2, Tabel 3 dan Tabel 4.

Tabel 2 Syarat mutu Garam konsumsi beryodium (SNI 3556:2000)

\begin{tabular}{|c|c|c|c|}
\hline No & Jenis uji & Satuan & Persyaratan \\
\hline 1 & $\begin{array}{l}\text { Kadar air } \quad(\mathrm{H} 2 \mathrm{O}) \\
(\mathrm{b} / \mathrm{b})\end{array}$ & $\%$ & maks. 7 \\
\hline 2 & $\begin{array}{lr}\text { Kadar } & \mathrm{NaCl} \\
\text { (natrium } & \text { klorida) } \\
\text { dihitung dari jumlah } & \text { klorida (Cl-) }\end{array}$ & & $\min 94,7$ \\
\hline 3 & $\begin{array}{lr}\text { Yodium } & \text { dihitung } \\
\text { sebagai } & \text { kalium } \\
\text { iodat }(\mathrm{KIO}) & \end{array}$ & $\mathrm{mg} / \mathrm{kg}$ & $\min .30$ \\
\hline 4 & Cemaran logam : & & \\
\hline 4.1 & Timbal (Pb) & $\mathrm{mg} / \mathrm{kg}$ & maks. 10,0 \\
\hline 4.2 & Tembaga $(\mathrm{Cu})$ & $\mathrm{mg} / \mathrm{kg}$ & maks. 10,0 \\
\hline 4.3 & Raksa (Hg) & $\mathrm{mg} / \mathrm{kg}$ & maks. 0,1 \\
\hline 6 & Arsen (As) & $\mathrm{mg} / \mathrm{kg}$ & maks. 0,1 \\
\hline \multicolumn{4}{|c|}{ CATATAN $1 \mathrm{~b} / \mathrm{b}$ adalah bobot/bobot } \\
\hline
\end{tabular}

Tabel 3 Syarat mutu Garam konsumsi beryodium (SNI 3556:2010)

\begin{tabular}{llll}
\hline No & \multicolumn{1}{c}{ Jenis uji } & Satuan & Persyaratan \\
\hline 1 & Kadar air (H2O) (b/b) & $\%$ & maks. 7 \\
2 & $\begin{array}{l}\text { Kadar } \mathrm{NaCl}(\text { natrium } \\
\text { klorida) dihitung dari } \\
\text { jumlah klorida (Cl-) }\end{array}$ & min 94 \\
$\begin{array}{l}\text { (b/b) adbk } \\
3\end{array}$ & $\begin{array}{l}\text { Bagian yang tidak } \\
\text { larut dalam air (b/b) } \\
\text { adbk }\end{array}$ & maks. 0,5 \\
\hline
\end{tabular}

Tabel 4 Syarat mutu Garam konsumsi beryodium (SNI 3556:2016)

\begin{tabular}{|c|c|c|c|}
\hline No & Parameter Uji & Satuan & Persyaratan \\
\hline 1 & Kadar air & $\begin{array}{l}\text { Fraksi } \\
\text { massa \% }\end{array}$ & maks. 7 \\
\hline 2 & $\begin{array}{l}\text { Kadar natrium } \\
\text { klorida }(\mathrm{NaCl}) \text { adbk }\end{array}$ & $\begin{array}{l}\text { Fraksi } \\
\text { massa \% }\end{array}$ & $\min 94$ \\
\hline 3 & $\begin{array}{l}\text { Bagian yang tidak } \\
\text { larut dalam air }(\mathrm{b} / \mathrm{b}) \\
\text { adbk }\end{array}$ & $\begin{array}{l}\text { Fraksi } \\
\text { massa \% }\end{array}$ & maks. 0,5 \\
\hline 4 & $\begin{array}{l}\text { Kadar yodium } \\
\text { sebagai } \mathrm{KIO} 3\end{array}$ & $\mathrm{mg} / \mathrm{kg}$ & $\min .30$ \\
\hline 5 & Cemaran logam : & & \\
\hline 5.1 & Kadmium (Cd) & $\mathrm{mg} / \mathrm{kg}$ & maks. 0,5 \\
\hline 5.2 & Timbal (Pb) & $\mathrm{mg} / \mathrm{kg}$ & maks. 10,0 \\
\hline 5.3 & Raksa (Hg) & $\mathrm{mg} / \mathrm{kg}$ & maks. 0,1 \\
\hline 6 & Arsen (As) & $\mathrm{mg} / \mathrm{kg}$ & maks. 0,1 \\
\hline
\end{tabular}

Dari table diatas terlihat bahwa perbedaan parameter uji untuk Kadar $\mathrm{NaCl}$ (natrium klorida) dihitung dari jumlah klorida (Cl-) awalnya dipersyaratkan maks 94,7\% kemudian direvisi pada tahun 2010 dan 2016 menjadi maks. 94\%. Bagian yang tidak larut dalam air (b/b) adbk yang awalnya tidak dipersyaratkan kemudian direvisi pada tahun 2010 dan 2016 menjadi maks. 0,5\%. Sedangkan cemaran logam kadmium yang awalnya tidak dipersyaratkan kemudian direvisi pada tahun 2010 dan 2016 menjadi maks. 0,5\%.

Faktor yang mempengaruhi kualitas garam yang kemudian menjadi kendala dalam proses produksi menurut Puska PDN, 2011 adalah:

a. Air laut yang bercampur dengan polutan dan air tawar, sehingga tentu berpengaruh pada produksi.

b. Curah hujan yang cukup tinggi di areal produksi, di beberapa tempat khususnya areal produksi garam musim kemarau yang berlangsung masih diselingi oleh hujan. 
Curah hujan di areal produksi garam Indonesia pada musim kemarau berkisar 100 - $300 \mathrm{~mm}$ per musim dengan tingkat kelembaban $60 \%$ - $80 \%$, sementara curah hujan pada musim kemarau di negara produsen garam dunia seperti Australia hanya berkisar $10-100 \mathrm{~mm}$ per musim dengan tingkat kelembaban $30 \%-40 \%$. Selain itu, musim kemarau di Indonesia juga berlangsung relatif lebih pendek jika dibandingkan dengan Australia dimana musim kemaraunya berlangsung selama 9 hingga 10 bulan. Dengan memperhatikan faktor tersebut, tingkat kecepatan penguapan di Indonesia relatif lebih lama.

c. Kualitas produk yang belum bisa memenuhi kebutuhan garam industri, konsekuensi yang ditimbulkan dari pembuatan garam dengan solar evaporation pada areal (petak) yang kecil adalah ketidak seragaman dari sisi kualitas. Garam rakyat memiliki kandungan $\mathrm{NaCl}$ berkisar $81 \%-96 \%$, sementara kadar $\mathrm{NaCl}$ yang dibutuhkan industri adalah ratarata di atas $95 \%$, meskipun ada beberapa yang di bawah $95 \%$.

Beberapa uji yang pernah dilakukan untuk mengetahui kualitas garam rakyat antara lain (Kementerian Kelautan Perikanan, 2014):

a. Hasil analisis uji sampel garam dari 42 Kabupaten/ Kotamadya kepada para penerima program PUGAR yang dilakukan oleh Universitas Diponegoro (UNDIP) pada tanggal 3 Juni 2013 menyatakan bahwa garam tersebut memiliki rata-rata kandungan $\mathrm{NaCl}$ 92,69\%, Kadar Air 2,24\%, Pb 8,9 ppm, Cu 3,23 ppm, Arsen 0 ppm;

b. Hasil pengujian laboratorium beberapa Industri Pengolahan Garam pada tahun 2014 menyatakan bahwa garam rakyat memiliki kandungan $\mathrm{NaCl}$ sebesar 81,1 - 86,91\%; kadar air $=9,68-9,77 \% ; \mathrm{Ca}=0,15-2,02 \%$; $\mathrm{Mg}=0,89-2,31 \%$, dimana hasil sampel diambil langsung dari tambak garam (Hasil Peninjauan Kemenko Perekonomian, Kemenperin, KKP dan Kemendag);

c. Hasil pengujian laboratorium garam bahan baku premium PT. Garam (2014) menyatakan bahwa garam tersebut memiliki kandungan $\mathrm{NaCL}$ (adbk) 95,47\% - 96,45\%, H2O: $0,24-6,23 \%$, Ca 0,22-0,58.

Perbedaan hasil yang cukup signifikan dari beberapa hasil uji tersebut terutama disebabkan oleh perbedaan sampel yang digunakan oleh masing-masing institusi. Dengan demikian, garam rakyat hingga saat ini masih belum mampu untuk memenuhi kebutuhan garam industri di dalam negeri yang mensyaratkan kualitas garam memiliki kandungan $\mathrm{NaCl}$ sebesar $85 \%$ hingga 99,8\% serta standar kandungan mineral lainnya yang terkandung di dalamnya serta dalam kuantitas yang juga cukup besar.

\subsection{Peran Pemangku Kepentingan}

Hingga saat ini banyak upaya dilakukan agar kualitas produksi garam petani meningkat, secara umum identifikasi permasalahan garam adalah: rendahnya kuantitas produksi garam dalam negeri, rendahnya kualitas garam yang diproduksi, ketersediaan lahan dan kurangnya pembinaan petani garam, daya tampung industri garam, perlunya pengembangan teknologi, Potensi pengembangan Standar Nasional Indonesia. Peran Pemerintah dalam membantu menyelesaikan permasalahan rendahnya kualitas dan kuantitas produksi garam dengan melakukan:

a. Pengembangan daerah-daerah potensial sentra industri garam ke wilayah Indonesia Timur untuk memperluas area tambak garam dengan mendorong intensifikasi lahan garam untuk meningkatkan jumlah produksi garam lokal. Musim kemarau di Pulau Jawa sekitar 4 bulan yang artinya masa produksi juga hanya 4 bulan, sementara di wilayah Indonesia Timur seperti di NTT musim kemarau dapat mencapai 8 bulan tidak turun hujan, dengan waktu kemarau yang panjang diharapkan bisa memproduksi garam 2 kali lipat yang ada di Pulau Jawa.

b. Program resi gudang untuk meminimalisair perbedaan persepsi pasokan garam lokal.

c. Pembinaan petani garam, dimana dalam pembinaan diperlukan tool antara lain SNI, sedangkan SNI yang belum tersedia adalah SNI terkait tata cara pemenuhan garam konsumsi, pemeliharaan tambak garam sangat bermanfaat yang dapat digunakan petani/UMKM sebagai acuan memproduksi garam.

d. Pengembangan Sistem Teknologi Ulir Filter (TUF) Geomembran yang dapat meningkatkan kualitas garam lokal sehingga bisa bersaing dengan garam impor (industri). TUF Geomembran adalah sebuah sistem, air laut yang dialirkan ke dalam kolam penampungan terlebih dahulu dilakukan filterisasi dengan menggunakan ijug sapu, batok kelapa dan batu zeolit. Menurut Triastuti S, 2010, kadar $\mathrm{NaCl}$ garam dapur dapat ditingkatkan secara efektif dengan pemurnian secara kristalisasi air tua menggunakan bahan pengikat pengotor, $\mathrm{Na} 2 \mathrm{C} 2 \mathrm{O} 4$ dan $\mathrm{Na} 2 \mathrm{CO} 3$ dibandingkan dengan $\mathrm{Na} 2 \mathrm{C} 2 \mathrm{O} 4$ dan $\mathrm{NaHCO} 3$. Kadar $\mathrm{NaCl}$ sebelum dimurnikan sebesar $80,117 \%$ meningkat menjadi $96,460 \%$. Produksi 
garam aneka pangan dapat dilakukan menggunakan bahan baku larutan brine sisa produksi garam farmasi dan bahan baku garam dengan $\mathrm{NaCl}$ berkualitas tinggi > 94\% serta kandungan $\mathrm{Ca}$ dan $\mathrm{Mg}<3000$ ppm serta dilakukan proses rekristalisasi secara sistem batch dengan maksimum penguapan 33\% (Rismana dan Nizar, 2014).

\section{KESIMPULAN}

Kebutuhan garam setiap tahun selalu meningkat seiring dengan bertambahnya jumlah penduduk dan pertumbuhan industri. Hingga Desember 2019 BSN telah menetapkan sebanyak 39 SNI terkait dengan garam. Berdasarkan SNI 3556:2016 Garam konsumsi beryodium, persyaratan kadar $\mathrm{NaCl}$ adbk minimal 94\% yang masih belum dapat dicapai oleh banyak petani garam. Peran mengembangkan SNI terkait tata cara pemenuhan garam konsumsi, pemeliharaan tambak garam sangat bermanfaat yang dapat digunakan petani/UMKM sebagai acuan memproduksi garam.

\section{UCAPAN TERIMA KASIH}

Penulis mengucapkan terima kasih yang sedalam-dalamnya kepada Allah SWT, Badan Standardisasi Nasional (BSN) yang telah memfasilitasi pelaksanaan penelitian, Komite Teknis Perumus SNI, rekan-rekan Staf yang telah membantu secara langsung maupun tidak dalam penyusunan KTI ini.

\section{DAFTAR PUSTAKA}

Agustina L.R, Citra Taslim, Danny. (2013). Rekristalisasi Garam Rakyat Dari Daerah Demak Untuk Mencapai SNI Garam Industri. Jurnal Teknologi Kimia dan Industri Volume 2 No.4 Tahun 2013. Hal: 217-225.UNDIP.

Assadad, L., Utomo, B. S. (2011). Pemanfaatan Garam Dalam Industri Pengolahan. Buletin Pascapanen dan Bioteknologi Kelautan dan Perikanan, Vol. 6 (1), pp. 26 - 37.

Badan Standardisasi Nasional. (2016). Sistem Informasi Standar Nasional Indonesia (SISNI) 2020.

BPS-UNICEF Report. (1995). National Survey on the status of lodine Defi ciency Disorder (IDD) in Indonesia.

Dharmayanti, S., Suharno \& A. Rifin. (2013). Analisis Ketersediaan Garam Menuju Pencapaian Swasembada Garam Nasional yang Berkelanjutan (Suatu
Pendekatan Model Dinamik). Jurnal Sosial Ekonomi. Vol.8 (1).

Hena Sugiani, Popy Previanti, Sukrido\& Uji Pratomo. (2015). Penentuan Pengaruh Pemanasan Dan Waktu Penyimpanan Garam Beryodium Terhadap Kalium lodat. Jurnal Chimica et Natura Acta Vol .3 No.2, Agustus 2015:66-69.

Hardiansyah, Haris. 2012. Metodologi Penelitian Kualitatif. Jakarta: Salemba Humanika.

Marihati dan Muryati. (2008). Pemisahan dan Pemanfaatan Bitern Sebagai Salah Satu Upaya Peningkatan Pendapatan Petani Garam. Buletin Penelitian dan Pengembangan Industri No.2 Volume II Tahun 2008. Semarang

Keputusan Presiden 69 Tahun 1994 tentang Pengadaan Garam Beryodium. Diunduh tanggal 20 Februari 2020.

Keputusan Menteri Perindustrian No. 29/M/SK/2/1995 tentang Penggunaan tanda SNI secara wajib terhadap 10 macam produk industri. Diunduh tanggal 20 Februari 2020.

Kementerian Koordinator Bidang Perekonomian, 2019, Laporan Tahunan 2019

Luthfi Assadad dan Bagus Sediadi Bandol Utomo. (2011). Pemanfaatan Garam Dalam Industri Pengolahan Produk Perikanan. Jurnal Squalen Vol. 6 No.1, Mei 2011

Peraturan Menteri Perindustrian No. 88/MIND/PER/10/2014 tentang perubahan atas Peraturan Menteri Perindustrian No. 134/M-IND/ PER/10/2009 tentang peta panduan (road map) pengembangan klaster industrigaram.

Rismana, E., Nizar. (2014). Kajian Proses Produksi Garam Aneka Pangan. Chemistry Progress, Vol. 7 (1), pp. 25-28.

Republik Indonesia. (2014), Undang-Undang Standardisasi dan Penilaiian Kesesuaian No.20 Tahun 2014.

Republik Indonesia. (2000), Peraturan Pemerintah No.102 Tahun 2002 tentang Standardisasi Nasional.

R.Djoko Mulyanto. Efek Defi siensi Yodium Pada Masyarakat, Fakultas Kedokteran-UNDIP, Semarang 1986.

Triastuti S, Warlan S, S Mantini RS. (2010). Pemurnian Garam Dapur Melalui Metode Kristalisasi Air Tua Dengan Bahan Pengikat Pengotor NA2C2O4 - NAHCO3 DAN NA2C2O4 - NA2CO3. Jurnal Sains dan Teknologi (Sainteknol). Vol. 8 No. 1 Juni 2010. Hal: 26-33. Universitas Negeri Semarang. 
